Article

\title{
Co-Producing Knowledge Innovation through Thematic Incubators for Disaster Risk Reduction and Sustainable Development in India
}

\author{
Sukhreet Bajwa ${ }^{1}$, Ambika Dabral ${ }^{1}\left(\mathbb{D}\right.$, Ranit Chatterjee ${ }^{1,2}\left(\mathbb{D}\right.$ and Rajib Shaw ${ }^{1,3, *(\mathbb{D}}$ \\ 1 Resilience Innovation Knowledge Academy, New Delhi 110059, India; sukhreet@rikaindia.com (S.B.); \\ ambika@rikaindia.com (A.D.); ranit@rikaindia.com (R.C.) \\ 2 Graduate School of Informatics, Kyoto University, Kyoto 606-8501, Japan \\ 3 Graduate School of Media and Governance, Keio University, Fujisawa 252-0882, Japan \\ * Correspondence: shaw@sfc.keio.ac.jp
}

check for updates

Citation: Bajwa, S.; Dabral, A.; Chatterjee, R.; Shaw, R. Co-Producing Knowledge Innovation through Thematic Incubators for Disaster Risk Reduction and Sustainable Development in India. Sustainability 2021, 13, 2044. https://doi.org/ $10.3390 /$ su13042044

Academic Editor:

Aurora Garrido-Moreno

Received: 1 November 2020

Accepted: 9 February 2021

Published: 14 February 2021

Publisher's Note: MDPI stays neutral with regard to jurisdictional claims in published maps and institutional affiliations.

Copyright: (c) 2021 by the authors. Licensee MDPI, Basel, Switzerland. This article is an open access article distributed under the terms and conditions of the Creative Commons Attribution (CC BY) license (https:/ / creativecommons.org/licenses/by/ $4.0 /)$.

\begin{abstract}
The private sector for long has been looked upon as a funding source to cushion the disaster and climate change damages and losses. In recent times, there is a more proactive approach with the private sector increasingly engaging in activities to promote Disaster Risk Reduction (DRR) and Sustainable Development Goals (SDGs) as a part of their business strategies. Despite significant strides being made by the private sector in this regard, the strategies that are good for the business, environment, and sustainability are yet to take off at a large-scale. Many private organizations are still facing the challenge of identifying the right target sector and stakeholders for fulfilling their sustainability requirements. However, the greatest strength of the private sector is its ability to innovate. As part of this innovative design, the concept of thematic incubation for corporate sustainability is explored. The products and services developed through these thematic incubators are envisaged to result in the achievement of global development agendas and promotion of sustainability performance for multiple stakeholders including government, academia, private sector, and the community at large. This concept allows a win-win situation with the culmination of long-lasting social and environmental goals along-with achieving profit-with-purpose. The paper identifies the concept of sustainability with respect to the interest of the stakeholders, as well as its alignment with that of sustainable development and disaster risk reduction. The paper presents an exploratory case of the thematic incubation for disaster risk reduction, climate change, and sustainable development as a possible approach to corporate sustainability. The paper details the process of thematic incubation along with possible challenges and advantages of the same. In all, thematic incubation has been identified as a lynchpin to ensure the effective utilization of resources and setting in motion a culture of innovation, entrepreneurship, use of science, and sustainability at the local level.
\end{abstract}

Keywords: thematic incubation; disaster risk reduction; sustainable development; social innovation; co-producing knowledge

\section{Introduction}

The year 2019 was a witness to 197 disasters events affecting millions of people across the globe [1]. The year 2020 began with an unprecedented pandemic of COVID-19, of which the impacts are not only long-term but are much beyond the health sectors. Besides, the huge lives lost, it has led to disruption and discontinuity in the normal functioning of the society, different sectors, businesses, etc., thereby leading to a global economic slowdown. Further, the occurrences of cyclone Harold in Southern Pacific Ocean, pest attack in parts of Africa, Middle East and South Asia, flash floods in Spain, Cyclone Amphan in India and Bangladesh, strong heat waves in different parts of Asia, followed by flooding and typhoon season, sporadic moderate to strong earthquakes, oil spill in the Arctic, and other hazard events highlight the increased frequency of disasters and the complex interplay of natural 
and human-induced hazards risk due to their simultaneous and cascading occurrence. The management of these risks calls for risk-informed and sustainable actions for safeguarding human life, reducing economic losses and strengthening systems and services. Global Assessment Report on Disaster Risk Reduction 2013 notes that the private sector, right from micro and small ventures to giant multinationals and corporations, was hit hard by some of the past disasters, though to varying degrees. Private sector is here comprised of a heterogeneous entity comprising large multinational companies, medium, small and micro enterprises. Disasters disrupt the global and local supply chains, affect markets, and erode the client base, thus forcing businesses to be shut down.

Sendai Framework for Disaster Risk Reduction (SFDRR) has emphasized new role of private sectors, focusing on innovation and knowledge co-production. The framework has also underlined the importance of higher education institutes, especially the universities to focus and contribute to innovative partnership-based research. That recommends an ideal combination of university business partnership for knowledge generation and innovation in the field of disaster risk reduction. In this paper, the basic concept of co-production of knowledge and innovation through thematic incubation is explored by reviewing different cases relevant to the field of disaster risk reduction. Finally, a specific example of thematic incubation from India is analyzed, and the key lessons are drawn from the incubation process, which is then generalized as future lessons.

A case study approach is taken up for the study as described in the following section. The following section brings forth the concept of incubators, evolution, and types. The next section studies the concept of corporate sustainability to understand the linkages with Sustainable Development Goals (SDGs) and Disaster Risk Reduction (DRR) and the challenges faced by the private sector in doing so. Various thematic gaps are discussed to understand the potential entry points for incubation and how corporate sustainability complements the ongoing global and regional dialogues on advancing the role of science here technology and innovation. Through Section 5, the paper tries to understand the co-production of knowledge through thematic incubators. The next section brings forth the learning from the existing thematic incubators aimed at nurturing innovation and research opportunities in the field of disaster risk management, climate change, and sustainability in India and Bangladesh. The last two sections discuss opportunities and challenges in establishing thematic incubators and the way forward to accelerate the private sector collaboration for promoting innovation and in supporting the global and local efforts towards building a resilient and sustainable society.

\section{Literature Review}

The whole-of-society approach, including the pro-active participation and collaboration by the private sector in all aspects of risk reduction and management, is the need of the hour. Engaging the private sector as part of the multi-stakeholder partnership is one of the points of confluence in the four global policies, namely the SFDRR, the 2030 Agenda for Sustainable Development, the Paris Climate Agreement, and the New Urban Agenda. The 3rd Asian Ministerial Conference on Disaster Risk Reduction (AMCDRR) has called for a shift in the role of the private sector from being a passive funding source to an active stakeholder in providing creative solutions [2]. Moreover, the private sector itself depends on a resilient public service infrastructure for the smooth functioning of its businesses; and thus, it is in the interest of the private sector to contribute to sustainable development and disaster and climate resilience. It is a win-win strategy for the society where the private sector brings in the much-needed resources, technical know-how, employment opportunities, and innovation for a stable and resilient society and economy on which its own functioning nurtures. The SFDRR resonates the above by explicitly stating "Business, professional associations and private sector financial institutions, including financial regulators and accounting bodies, as well as philanthropic foundations, to (i) integrate disaster risk management, including business continuity, into business models and practices through disaster-risk-informed investments, especially in micro, small and 
medium-sized enterprises; (ii) engage in and support research and innovation; and (iii) share and disseminate knowledge, practices and non-sensitive data;" (UN, 2015).

Besides, there has also been an increasing expectation from the private sector to integrate the principles of sustainability into their business models which has led to a new and emerging paradigm of corporate sustainability [3]. The new paradigm provides for an increased role of the private sector in disaster risk governance and sustainable development through its Environmental, Social and Governance (ESG) factors. The integration of ESG aspects into business help the private sector in not only lowering the risk but also in building the right perception of the business among the investors, thereby contributing to revenue growth, profitability and building the brand value. It is noteworthy that the action of the private sector in the field of sustainability and DRR have been evolving for better and there is an increasing awareness about the same amongst the private sector along with active participation in varied aspects including support for the laid down programs and policies in the said fields. However, many private players are still keeping a cautious attitude because of their perception that such efforts are inconsistent with their immediate economic interests [4]. The private sector also faces the challenge of finding the right direction and approach to align their business with ESG factors, SDGs, and DRR.

Considering the need to build resiliency into the concept of sustainable society to counter potential challenges posed by hazards, it is important that the private sector fulfil its obligation for corporate sustainability. Research highlights that knowledge products aimed at sustainability are more effective when co-produced [5]. The idea of co-production of knowledge through a multi-stakeholder approach enhances the relevance of citizen science in the society [6]. This paper explores and recommends thematic incubators for sustainable development and DRR as an innovative approach towards co-production of knowledge to promote corporate sustainability. The co-production of knowledge in this context refers to coming together of stakeholders enabling the science-policy-research interface to design innovative solutions for sustainability. The thematic incubation is an innovative approach to bring in co-created knowledge to address local issues by bringing the private sector, local authority, academia and citizens on the same platform to enhance the role of Science and Technology and innovation in disaster management. Further, this approach will handhold with budding young entrepreneurs and address issue of unemployment at the local level. As per Reference [7], co-production of knowledge is the required approach to enhance innovation in disaster risk reduction. Innovation is not limited to creation of new products, but also new processes of implementation of knowledge. Similarly, DRR innovations pertain to use of science and technology and community knowledge to integrate effectively into the decision-making process (ibid.). The process of co-creation does not only relate to knowledge creation but also dissemination of that knowledge at the grassroot level (ibid.). The thematic incubation is a process of application of knowledge into practice in a shared way. A study by PricewaterhouseCoopers Private Limited (PwC) highlighted that it was important for investors in private companies to know about the ESG factors, but there was insufficient information regarding the same [8]. The study underscores the need for bridging the communication gap between the investors and the corporates on the need to include ESG factors (ibid.). The term ESG was first introduced in 2004 as part of the Who Cares Wins: Connecting Financial Markets to a Changing World report by UN Global Compact. It sought to address the central issue of integrating ESG value drivers into corporate strategies concerning market research, analysis, and investment [9]. A major breakthrough came when ESG strategies started impacting revenue growth [10]. The environmental factor assesses the performance of an organization in safeguarding the environment and its compliance to environmental laws and includes aspects, like conservation of natural resources, contribution to pollution, energy usage, waste management, etc. The social factor evaluates an organization's relationship vis-a-vis its employees, shareholders, and stakeholders, including the local community, etc. The factor of governance inspects into the elements of transparency to shareholders, the accuracy of accounting methods, conflict of interests, etc., in the functioning of the business [11]. 
Corporate Sustainability can be explored through various approaches. The stakeholder theory defines a stakeholder as 'any group or individual who can affect or is affected by the achievement of the organization's objectives' [12]. The basic premise of this approach is that the stronger the relationship of an organization is with its external parties, the easier it is to meet the business objectives. It suggests that it is in the company's own best economic interest to work in the direction of sustainable development so as to strengthen the relationship with stakeholders. The accountability approach puts a legal and ethical responsibility on the company to provide an account of their actions. This approach puts the private sector in a stricter spot as compared to mere corporate responsibility. Accountability differs from responsibility in that the latter refers to one's duty to act in a certain way, whereas accountability refers to one's duty to explain, justify, or report on his or her actions. Accountability ensures enforcement of the just actions by the organizations [13]. The institutional theory [14] explains the important role played by scientific institutions and academic research institutions in the development of nations. Further, (ibid.) has established the impact of institutions in developing entrepreneurial risk-taking behavior in the community. The social network theory [15], places importance on the role of social networks in building an organization. It gives precedence to relationship ties over individual attributes. It highlights the opportunities and chances for growth and career development owing to the structure of social networks (ibid.).

Thematic incubators have huge potential to act as the platform which connects these different approaches to corporate sustainability. The term incubator is derived from the basic meaning of the term nurturing, which is to develop small companies in a protected environment [16]. Incubators are a perfect way to enhance partnership and co-design innovation and knowledge products to enhance inclusion of sustainability factors by a corporate.

\section{Methods}

The paper uses the secondary literature to study the key concepts of corporate sustainability, incubators, disaster risk reduction, and sustainable development to identify the gaps and challenges private sector faces in fulfillment of their obligations towards the same. Based on this, the paper proposes a conceptual framework for the thematic incubation for corporate sustainability. An exploratory case study method is used to understand the implementation process and challenges of the proposed conceptual framework. "You can express and defend your intention to do a case study because it represents a unique case, deserving to be studied on its own right" [17].

In the backdrop of the concerns regarding the limitations of quantitative studies in gauging the holistic and in-depth understanding of social and behavioral questions, the case study approach has gained recognition as a research tool for many social sciences studies [18]. The approach is well recognized in the fields of business, law, and policy [19]. The case study approach, through exploration and examination of past and existing studies, provides multi-facet understanding of complex issues. By including both quantitative and qualitative data, the case study approach allows for understanding both the process and outcome of a phenomenon through complete observation, reconstruction and analysis of the cases under study (Tellis, 1997) as cited in Reference [18]. A case study approach is preferred when examining a contemporary subject within its real-world context $[17,18]$. Thus, the paper uses an exploratory and descriptive case study approach to investigate the contemporary concept of thematic incubation and the potential opportunities it provides towards fulfilling ESG factors of corporate sustainability.

Cases were selected from the diverse institutes in India, from premium technical institutes (like Indian Institute of Technology (IIT)) to regular universities, government research entities, as well as private thematic research hubs and stand-alone incubators. Couple of incubators from abroad are also analyzed. Most of the incubators studied in this paper focus on technology-based innovation, while the examples from Europe focus on SDGs and social innovation. Some of the incubators hold specific physical facilities, 
where the students/youths from different disciplines are gathered, while, in some other incubations, virtual incubation is provided. Thus, the choices of the case studies were based on: (1) diversity of themes, (2) diversity of host institutes, and (3) diversity of incubation mechanisms.

"The essence of a case study, the central tendency among all types of case study is that it tries to illuminate a decision or set of decisions, why they were taken, how they were implemented and with what results" (Schramm, 1971), as cited in Reference [17]. Using this approach, the paper details the process of setting up thematic incubators in the field of disaster risk reduction, climate change and sustainability along-with possible challenges and advantages of the same. The case study approach has helped in examining the process of establishment of a thematic incubator at a micro-level. By studying the thematic incubators in the field of disaster risk reduction, climate change, and sustainability which have implemented the concept on field, the paper provides for wider replication of this concept, especially for the private sector as a potential tool of corporate sustainability.

\section{Incubators}

The concept of the incubator originated in the early 1950s in the United States. Incubators act as launchpads for ideas to become implementable projects. They support entrepreneurs in the start-up and early development of technology ideas. They help entrepreneurs develop their ideas to greater maturity by supporting them with training, guidance and networking on technical, financial and other issues. They also support them with partnerships, business models, and fundraising.

The first formal business incubator was the Batavia Industrial Center in the United States in 1957. However, the substantial boom of the incubators was not witnessed until the 1980s, which saw a rise in computers and technologies. Later, in the early 2000s, with the coming of angel investment, investors radically transformed the early-stage entrepreneurial support, both in terms of financial and human capital, leading to the development of the global entrepreneurial ecosystem [20]. The early business incubators focused on providing low-cost space and a small set of shared services. In the second phase, knowledge-based services were added in order to help entrepreneurs start businesses and learn, including training, coaching, and mentoring. The third phase focused on providing network access, helping to overcome resource scarcity and acquire specialized expertise to grow faster. The fourth phase referred to the coming up of e-commerce giants, logistics, marketplaces, and advertising firms.

Currently, while the majority of the incubators are established and managed by industry professionals and private and public organizations, some universities also host incubators to mentor and encourage future entrepreneurs, who can translate various targets into meaningful actions on the ground. The government/public sector backed incubation set up, as witnessed in India, has provided ample support to youth and to bring in a culture of start-up activities. Every year more than 800 technology start-ups are being set up in India. By 2020, 11,500 tech-startups were estimated to be established as per a 2015 report of The National Association of Software and Service Companies (NASSCOM) [21]. The Start-up India initiative of the Government of India supports incubators attached to premier academic institutes [22]. This government backed initiative provides infrastructural, financial and networking support to the incubators. Incubators may provide for product innovation (development of new creative products), process innovation (alternative ways in which products are created), position innovation (involving how products are introduced in the market), and paradigm innovation (involving shifting of perception) [23]. Technology Business Incubators (TBIs) help usher the wider proliferation of innovative tech-driven enterprises.

Incubators can be categorized into four categories as listed below:

(i) business incubators seek to support development of new ideas/initiatives by providing services, such as management training, capital funding options, and handholding in providing other support in the initial phase of a setup; 
(ii) university incubators aim at commercializing technology;

(iii) research incubators seek to attach a commercial or social value to research; and

(iv) stand-alone incubators focus on selecting and supporting nascent ventures with high potential.

Incubators versus Accelerators: Incubators "incubate" ideas with the hope of building out a business model and company, whereas the accelerators "accelerate or speed up" the growth of an existing company. Accelerator programs usually have a set timeframe in which individual companies can spend between a few weeks to a few months working with a group of mentors to build out their business [24]. While accelerators might begin with start-ups, incubators begin with an idea which may take the form of a start-up.

\section{Corporate Sustainability and Thematic Incubators}

Corporate sustainability differs from traditional growth and profit-maximization model in recognizing that, while financial growth and profitability are important, an organization should also pursue societal goals, specifically those related to sustainable development, like environmental protection, social justice and equity, and economic development [25]. Historically, the concept has been of much interest to social sciences research since the mid-1990s and has further evolved as a result of economic growth, stewardship of environmental regulations and a push for social justice and equity [25]. Over the years, triggered by environmental pollution, dumping of toxic wastes, and industrial disasters, global interest has emerged among industries, government, and non-governmental organizations to collaborate and exercise the shared responsibility for preserving the environment and its natural resources (ibid.). John Elkington coined the term 'triple bottom line' in 1994 to advance the sustainability agenda. It aims to broaden the understanding of sustainability beyond the concept of sustainable development and corporate social responsibility to an integrated approach of doing business which focuses on economic prosperity, social development, and environment quality [26]. These developments led to a shift in the focus of the private sector from one bottom line of profitability to working with a focus on the triple bottom line of 3Ps: Planet, People, and Profit.

Importance of corporate sustainability, its ESG factors and the active participation of the private sector in fulfilling SDGs and DRR can be implicitly traced in the recent global agreements and agendas on disaster risk reduction, sustainable development, climate change action. The Priority of Action 3 under SFDRR- 'investing in disaster risk for resilience' calls for private sector investment and cooperation along with building business resilience. The 2030 Agenda for Sustainable Development highlights the need for responsible businesses, sustainability, partnership and investment in innovation. The Paris Climate Agreement lays emphasis on climate finance, technology, and climate-friendly investments. The New Urban Agenda focuses on environmental sustainability, inclusivity and publicprivate partnership. The ARISE (the Private Sector Alliance for Disaster Resilient Societies) Initiative led by the United Nations Office for Disaster Risk Reduction (UNDRR) endeavors to increase the private sector's participation in DRR. As per Reference [27], the linkage of sustainability and SDGs to the corporate interest is either business-driven or valuedriven. Business-case drivers involve maximizing growth opportunities and minimizing risk, while value-case drivers adopt values or purpose statements that move the corporate strategy beyond just financial return. Overall, the SDGs provide a useful framework, both internally and externally, to organize and articulate a company's sustainability goals (ibid.). Further, there is an overlap in the thematic development areas of both the Corporate Social Responsibility (CSR) and SDGs, and, together, they have tremendous potential to develop an interconnected model for sustainable growth [28].

Private players working in different business and regulatory landscapes often find it difficult to identify best practices of sustainability integration in their respective sectors [27]. Further, many private players are still facing the challenge of prioritizing sustainability requirements for efficient allocation of limited resources. Often, these requirements are finalized considering the interests of direct stakeholders like customers, shareholders and 
government. The interests of indirect stakeholders, like the community in general, civil organizations, etc., fail to find a place in these requirements [4]. The need still remains to engage the private sector in meeting the SDGs in a way that not only helps in better management of their social, environmental, and economic performance but results in the development of smart businesses that capture opportunities and come up with innovative products and services to achieve the highest standards of sustainability [27].

Scientific evidence suggests better targeting and investing in disaster risk management and sustainable development. Reference [29] brings forth some of the common barriers to the scaling-up of private investments in corporate sustainability. It is observed that sustainability is not being integrated into long-term business strategy and is perceived as divergent priorities; hence, it is often not valued in internal capital allocation decisions. Businesses continue to manage sustainability factors as a siloed function without associating them with value creation. In many cases, they fail to comprehend and factor in external costs like environmental impacts on society, thus making inaccurate assumptions about the cost to the company or missing potential risks to the businesses.

Sustainability is a broader term referring to managing resources in a way that guarantees welfare and promotes equity of current and future generations [30]. Resilience means the ability of a system, community, or society exposed to hazards to resist, absorb, accommodate, and recover from the effects of the hazard in a timely and efficient manner, including through the preservation and restoration of its essential basic structures and functions (UNDRR). While sustainability is described as prioritizing desired outcomes, resilience prioritizes the processes [31]. As per Reference [10], both resilience and sustainability are important functions for the private sector to feature in their strategies. Hence, thematic incubators by private players with a focus on risk resilience can prove to be addressing the twin goals of resilience and sustainability.

\section{Co-Producing Knowledge Innovation through Thematic Incubators}

The process of co-production of knowledge involves collaboration and interaction between researchers and practitioners. It delves through trans-disciplinary approach which can be explored through thematic understanding. Further, the engagement of multiple stakeholders has to be even throughout the various phases of the knowledge production. The earlier research undertaken in the field of studying the co-production of knowledge highlight the elements of design, and implementation and context and inputs features [6]. The process of setting a platform to enable the varied inputs, context and a shared vision for the output needs to be institutionalized. The knowledge co-production tends to go adrift with diversity of expertise in a collaborative group. The process thereby requires locating the context, recognizing the plurality of approach and articulation of shared goals [32]. The contextual setting is important for application of knowledge to practice. This requires a balance of technology and social science understanding. The concept of thematic incubators not only facilitates the shared interaction in the initial stage, but the hand-holding process is undertaken for co-production of knowledge, as well as innovative products.

The concept of thematic incubators in the field of sustainable development is in formative phase. There are only a few incubators globally to promote the confluence of business ideas for sustainability, risk resilience, and risk reduction. Thematic incubation with a focus on sustainability can be traced to the post-2015, which saw a major shift in global policy on sustainable development, disaster risk reduction, and climate change action. Being in formative stage, there is a great scope of experimenting with varying themes and allows the private sector to single out on a relevant theme based on their current business product, process, geographical region, or based on the interest of the stakeholders. These themes can vary from disaster risk reduction, safety, sustainable development, women entrepreneurship, conflict and peace, heritage risk management, citizen science, etc.

Figure 1 presents the conceptual framework for thematic incubators as an approach to co-production of knowledge innovation for sustainability. It brings together the concept of 
sustainability and resilience as laid down within the global agendas and agreements on disaster risk reduction, climate change action, and sustainable and urban development. The four key partners for knowledge co-production identified under the framework are community, government and multilateral organizations, academia, and the private sector. These four partners can collaboratively support each other in identifying and focusing on the convergent themes under the global and local agendas. The convergent themes bring out the inter-connected sectors and stakeholders which form the basis of innovation for products and services. A possible lens for identifying the themes of convergence could be through exploring three key aspects, namely (a) socio-economic issues of the community, (b) existing and potential products, services (both natural and human-built), and infrastructure exacerbating or mitigating these issues, and (c) the prevailing risk governance mechanism. The framework is well-aligned with ESG factors of corporate sustainability and also fits well within the approach of triple bottom line focusing on 3Ps-People, Profit, and Planet-and, thus, can be an appropriate approach to corporate sustainability.

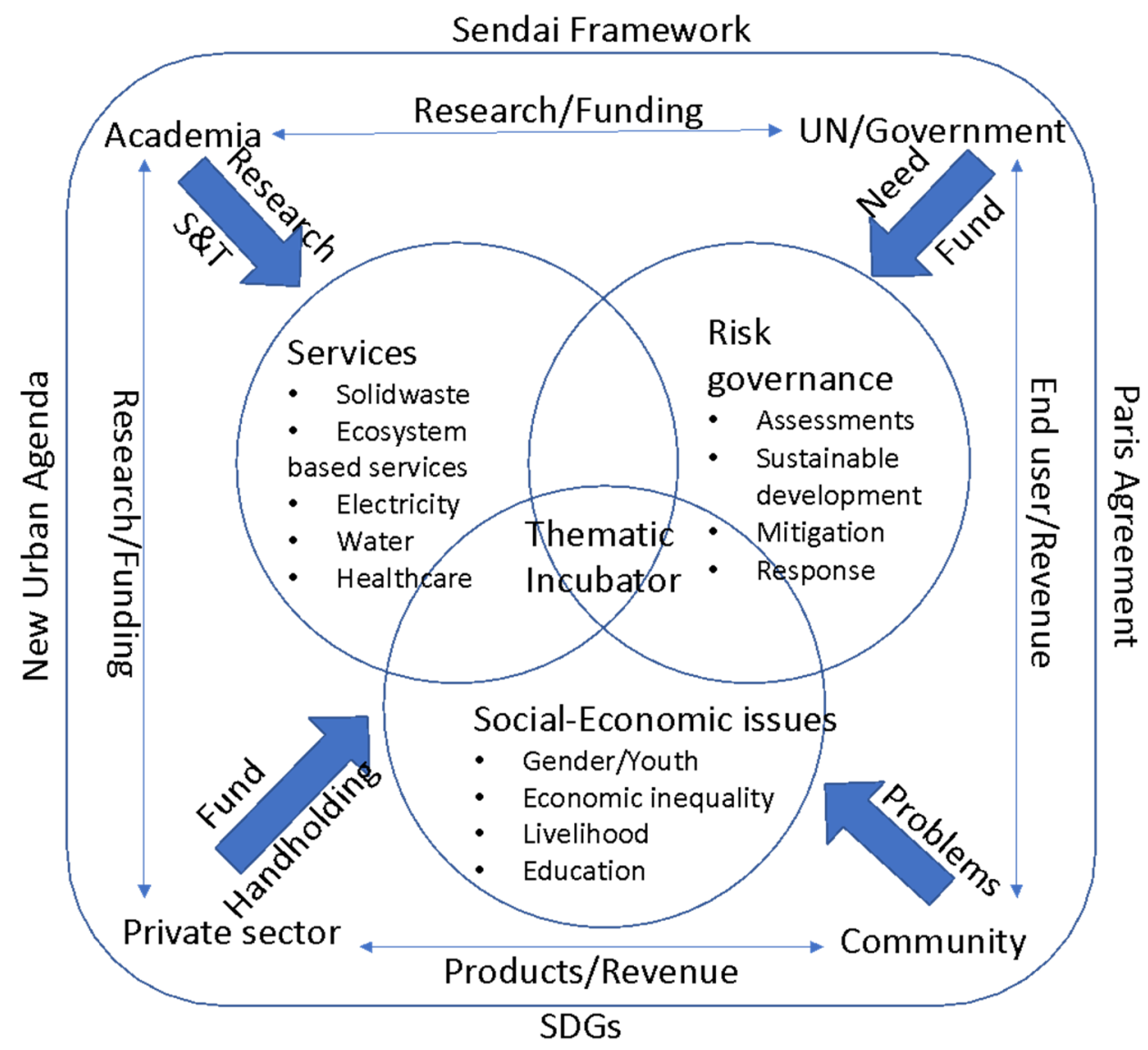

Figure 1. Conceptual framework for thematic incubator.

A multi-stakeholder thematic incubator is a win-win strategy for all as it provides a platform for all the partners to both contribute and also to benefit from others. While the community can contribute in the identification of local problems and local resources and pitching in local and traditional knowledge, academia can support with undertaking research and providing innovative solutions, the private sector can provide funding and technical support for nurturing such innovative solutions and developing useful product and services, and the government can support by providing relevant administrative and technical support through its existing institutional mechanism. The government can also support in replicating the appropriate solutions to other communities. By implementing this, the community is benefited by an appropriate solution to their problems, the government is benefited by successfully delivering the services to its citizens, academia is 
benefited by the research and testing support to its innovative ideas, and the private sector is benefitted by fulling not only its ESG obligations but also building a robust relationship with the community-its potential customers. Based on the appropriateness and marketability of the solution, the same can be commercialized and made available to masses at large.

\section{Thematic Incubators}

While, in general, incubators exist in varied sectors and focus on varied disciplines, the ones with a focus on specific subjects and whose business idea flourishes around that particular theme are called thematic incubators. Having a specified theme allows the focus on solving a pertinent problem or agenda. The themes may vary as per the needs of the society and interest of the stakeholders. Historically, small enterprises have played an important role in technological innovation, often leading to paradigm-shifting technologies and changes in the way we live. However, they face many challenges in maturing/commercializing to a point where they could survive and have positive social, environmental, and economic impacts [33]. Thematic incubators supported by the private sector can play a significant role in addressing these challenges by hand-holding the small firms, entrepreneurs, like-minded individuals, academicians, etc., and providing them an ecosystem for development of product and services to meet societal and environmental needs. Thus, the private sector, through these thematic incubators, has an immense potential to catalyze the development of more sustainable and climate and disaster resilient infrastructure, services, and societies.

The process of thematic incubation includes commercializing the sustainable business approach in line with global development agendas. For example, the thematic incubator can play an important role in the promotion of new low-emission and climate and disaster risk-resilient technologies [34], which aid in not only fulfilling the ESG factors of corporate sustainability but also align the functioning of the organization with the needs of its stakeholders and ecosystem and further enhance its accountability towards them through multi-stakeholder partnerships.

\subsection{Existing Case of Thematic Incubators}

Institutionalization of the thematic incubator can help in building a culture of entrepreneurship and innovation in the society, thereby providing opportunities for growth and career development. In the Indian context, incubation infrastructure is dominated by use of technology for commercialization. Incubation in the context of sustainability and to address social sector problems is not yet fully explored. However, the thematic incubation approach for sustainability and the achievement of SDGs has been initiated at the global level. Further, the examples (Table 1) present the scope of incubators as a social entrepreneurial activity that aims to create a positive impact on the planet. Social enterprise means going beyond revenue and profit and integrating sustainability as a core activity [35]. Table 1 lists down cases that present the need to have allied industries, like big data and logistics, to achieve sustainability so as to make a contribution towards SDGs and disaster resilience. In total, 12 cases were selected with variation of themes, host institutes, and incubation mechanisms. A case-based method was used to analyze selected cases and to draw key lessons. The case-based method made qualitative analysis of: (1) stakeholder participation and involvement, (2) gender responsive innovation, (3) youth participation and role in leadership in innovation, and (4) specific focus on public health dimension, especially during the COVID-19 pandemic situation. The key findings are summarized in the next section. 
Table 1. Existing cases of incubators.

\begin{tabular}{|c|c|c|c|}
\hline Incubator & Host Entity & Target Audience & Key Features/Focus on Sustainability \\
\hline $\begin{array}{l}\text { Technology and Business } \\
\text { Incubator (TBI) [36] }\end{array}$ & $\begin{array}{c}\text { IIT Delhi, } \\
\text { University Incubator }\end{array}$ & $\begin{array}{l}\text { Students, Alumni and } \\
\text { Academic Staff Members }\end{array}$ & $\begin{array}{l}\text { Focuses on Technology based } \\
\text { entrepreneurship }\end{array}$ \\
\hline $\begin{array}{l}\text { Society for Innovation and } \\
\text { Entrepreneurship } \\
\text { (SINE) [37] }\end{array}$ & $\begin{array}{l}\text { IIT Mumbai, } \\
\text { University Incubator }\end{array}$ & IIT Students and Faculty & $\begin{array}{l}\text { Focuses on technology-based } \\
\text { entrepreneurship }\end{array}$ \\
\hline $\begin{array}{l}\text { Atal Incubation Centers, } \\
\text { Atal Innovation } \\
\text { Mission [38] }\end{array}$ & $\begin{array}{l}\text { Government of } \\
\text { India Initiative }\end{array}$ & $\begin{array}{c}\text { Umbrella Innovation } \\
\text { Organization to support } \\
\text { incubators at university, } \\
\text { corporate, } \\
\text { Non-Governmental } \\
\text { Organization (NGO) and } \\
\text { Small and Medium } \\
\text { Enterprises (SME) level }\end{array}$ & $\begin{array}{l}\text { Focuses on creating incubation centers in } \\
\text { public and private sector, as well as } \\
\text { scaling up existing incubation centers }\end{array}$ \\
\hline $\begin{array}{l}\text { International Centre for } \\
\text { Entrepreneurship and } \\
\text { Technology-iCreate, } \\
\text { Ahmedabad [39] }\end{array}$ & $\begin{array}{c}\text { Autonomous Centre of } \\
\text { Excellence (Business } \\
\text { Incubator) } \\
\text { Government of Gujarat } \\
\text { initiative of Gujarat } \\
\text { Foundation of } \\
\text { Entrepreneurial Excellence } \\
\text { and a joint venture of } \\
\text { Gujarat Mineral } \\
\text { Development Corporation } \\
\text { Limited and Gujarat } \\
\text { Entrepreneurship and } \\
\text { Venture Promotion } \\
\text { Foundation }\end{array}$ & $\begin{array}{c}\text { Students, Public, } \\
\text { Industries, Small } \\
\text { Businesses, Academicians }\end{array}$ & $\begin{array}{l}\text { Undertakes grooming with or without a } \\
\text { project idea to inculcate entrepreneurial } \\
\text { skills and mindset }\end{array}$ \\
\hline
\end{tabular}

Centre for Innovation

Incubation and

Entrepreneurship, Indian

Institute of Management

University Incubator Alumni and Students

Virtual Incubation Model

(IIM) Ahmedabad [40]

Technology Incubation Centre (T-hub),

International Institute of Information Technology (IIIT) Hyderabad,

Government of Telangana (GoT) [41]

Bangalore Bio-Innovation,
Government of
Karnataka [42]

10 X Mobile Start-up hub, Government of Karnataka [42]
PPP model between the

GoT, IIIT-H, Indian School

of Business (ISB) \&

National Academy of

Legal Studies and Research

(NALSAR) and key

private sector leaders.

Business Incubator

Bangalore Helix
Biotechnology Park, Start-ups in Life Sciences
Electronic City

Business Incubator

Start-ups, Corporates

Helps with access to technology, Business Network and Funding.

Enabled ventures like Banyan Nation and Sanshodhan-E Waste Exchange which focus on Environmental Sustainability
Initiative of Government of Karnataka in partnership with Internet and Mobile Association of India (IAMAI)

Business Incubator Supports Centre for Cellular and
Molecular Platforms (C-CAMP): COVID-19 Innovations Deployment Accelerator
Start-ups in mobile based applications
Promotes innovation and entrepreneurship in mobile based application technology development

$\begin{array}{ccc}\text { SDG Incubator, Corporate } & & \text { Existing businesses which } \\ \text { Sustainability and } & \text { European Business } & \text { aim to enhance } \\ \text { Responsibility (CSR) } & \text { Network for CSR, Europe } & \text { sustainable growth } \\ \text { Europe [43] } & & \end{array}$

The objective of this incubator is to incubate collaborative action towards one or several SDGs through the creation of multi-stakeholder partnerships 
Table 1. Cont.

\begin{tabular}{|c|c|c|c|}
\hline Incubator & Host Entity & Target Audience & Key Features/Focus on Sustainability \\
\hline $\begin{array}{c}\text { Citizen Science for } 2030 \\
\text { Agenda [44] }\end{array}$ & $\begin{array}{l}\text { Global Young Academy } \\
\text { (GYA) currently located at } \\
\text { German National } \\
\text { Academy of } \\
\text { Sciences Leopoldina }\end{array}$ & GYA Members & $\begin{array}{l}\text { It aims to utilize the potential of citizen } \\
\text { science as an approach for increasing the } \\
\text { community's engagement with the SDGs }\end{array}$ \\
\hline $\begin{array}{l}\text { Google Accelerator } \\
\text { Program [45] }\end{array}$ & Google & $\begin{array}{l}\text { Existing Businesses } \\
\text { and Start-ups }\end{array}$ & $\begin{array}{c}\text { It aims to empower technology start-ups } \\
\text { to build and scale viable social impact } \\
\text { companies so as to solve some of the } \\
\text { world's problems }\end{array}$ \\
\hline $\begin{array}{c}\text { SDG Impact } \\
\text { Accelerator [46] }\end{array}$ & $\begin{array}{l}\text { Multi-stakeholder } \\
\text { platform }\end{array}$ & $\begin{array}{l}\text { Established Companies, } \\
\text { NGOs, Start-ups, } \\
\text { Universities }\end{array}$ & $\begin{array}{l}\text { It aims to create market innovations } \\
\text { focusing on a particular solution. The } \\
\text { aim is to build a model for accelerating } \\
\text { the discovery and market entry of } \\
\text { solutions for the big problems like the } \\
\text { refugee populations in the Least } \\
\text { Developed Countries (LDCs). It focuses } \\
\text { on two main themes: } \\
\text { Big Data and Sustainable Develop- } \\
\text { ment } \\
\text { - Sustainability Logistics }\end{array}$ \\
\hline
\end{tabular}

\subsection{Key Entry Points of Thematic Incubation}

\subsubsection{Enhanced Use of Science and Technology}

Science, Technology \& Innovation (STI) is an important key to enhance productivity, economic prosperity, and environmental sustainability [47]. Science and technology feature strongly as a cross-cutting theme across the various sectoral targets of SDGs (ibid.) also points out that creation, diffusion of new technologies, and innovations strengthen knowledge sharing and collaboration. Countries with extensive use of science and technology have been known to be more prosperous with more productivity [48]. The increase in productivity is directly linked to innovation. The use of science and technology provides an evidence-based support to innovative theories and ideas. It also enables one to measure the results and determine progress. The lack of innovative use of science and technology is attributed to less investment in building research capacities. Investment in scientific research needs to be coupled with parallel investment in socio-economic structures that facilitate co-creation of knowledge [49].

\subsubsection{Multi-Stakeholder Partnership for Sustainability}

SDG 17, which reads "Strengthen the means of implementation and revitalize the Global Partnership for Sustainable Development", recognizes multi-stakeholder partnerships as important vehicles for mobilizing and sharing knowledge, expertise, technologies, and financial resources to support the achievement of the sustainable development goals in all countries, particularly developing countries. Goal 17 further seeks to encourage and promote effective public, public-private, and civil society partnerships, building on the experience and resourcing strategies of partnerships. In the context of urbanization and sustainability, Reference [50] stresses the role of people along with private and public sectors to make the cities a "living lab" for sustainable development. Urban sustainability has a resource strength of people and organizations that are linked and are working in a variety of ways on common problems. Urban innovators (People) try to focus on market failures as an opportunity to address the issues of the efficacy of essential services and societal well-being [29]. A city to be creative, intelligent, and sustainable needs to bring people at the center of urban governance [51]. The rapid urbanization across the globe has made the cities a hotspot of hazard risks due to gaps in meeting demand for essential services, 
socio-economic and cultural wellbeing. Every disaster widens this gap, hence, requiring a platform to channelize the multi-stakeholder partnerships for sustainability. Thematic partnerships of the private sector with the sustainability agenda [52] is a systematic approach to achieving the development goals. Active engagement between the different stakeholders, disciplines, and cultures in a participatory way helps to combine both bottom-up and top-down innovation processes through creating co-creative partnerships $[50,51]$.

\subsubsection{Increasing Youth Participation}

As discussed in the preceding part, to foster innovation, a key component is collaborations and partnerships. The Science and Technology Roadmap for SFDRR acknowledges the need to empower and strengthen the role of youth and young professionals so as to achieve the targets under SFDRR [53]. The voice of the youth has become important in bringing lawmakers to change various laws and policies related to environment and climate change [54]. Engaging youth in entrepreneurial ventures has a significant impact on the socio-economic landscape of a country. There are many domains where youth-led innovations have inspired the corporates to commercialize the idea. However, there are not many platforms for youth to engage in entrepreneurial activities. In the current situation of increasing unemployment, entrepreneurship training can provide a solution to tackle the problem. Further, there is a pressing need to encourage young professionals to undertake social entrepreneurial ventures.

\subsubsection{Reducing Gender Divide and Women Empowerment}

Women constitute around 50 percent of the world population; however, across countries, they own and manage significantly fewer businesses than men (Georgellis and Wall, 2005; Kim, 2007), as cited in Reference [55]. Entrepreneurship is one avenue through which women can break the glass ceiling encountered within organizations. Paragraph 26 of the Beijing Declaration and Platform for Action adopted at the Fourth World Conference on Women (1995) mentions a clear commitment to: 'promote women's economic independence, including employment, and eradicate the persistent and increasing burden of poverty on women by addressing the structural causes of poverty through changes in economic structures, ensuring equal access for all women, including those in rural areas, as vital development agents, to productive resources, opportunities and public services'. The SDG 5 aims to achieve women empowerment as a part of the global agenda. Women entrepreneurship is also a window to gain control over opportunities, performance evaluations, and to create a more pleasant work environment. It is established that women entrepreneurs are more likely than men to be innovative in their businesses [56]. Engagement of women at leadership positions and as decision-makers with financial autonomy can speed up the progress for SDG 5 and SFDRR priority 4 .

\subsubsection{Addressing Public Health Concerns}

The intersection of health and DRR is emerging as an interdisciplinary field of paramount human consequences in the COVID-19 Pandemic. The Health Emergency and Disaster Risk Management (Health-EDRM) is an evolving academic approach that combines Health Emergency and Disaster Risk Management [57]. Currently, public health needs are not directly addressed by the private sector as part of its sustainability approach. The pandemic has increased unemployment, thereby increasing stress in the households, which has in turn increased the cases of domestic violence. However, access to gender-based violence services are disrupted due to pandemic [58]. The private sector's engagement in public health-related innovative solutions would allow them to take care of their workforce and build trust.

\section{Resilience Innovation Knowledge Academy (RIKA) Initiatives of Thematic Incubation}

RIKA India Pvt. Ltd. (a research-based social entrepreneurial start-up in New Delhi, India) has taken the lead in establishing thematic incubators in partnership with uni- 
versities. The themes have been explored based on the regional issues, as well as the specialization of the courses of the academic institutes. Mody University at Rajasthan, India, which is an all-women university has the theme of women leadership in DRR and climate change. The National Institute of Technology (NIT), Nagpur, has the theme of smart city and climate change adaptation, while Brac University at Dhaka has the theme of urban sustainability and design. This section analyzes the incubation process RIKA has initiated based on previous learning from the case studies. The section also specifies key points of: (1) designing the incubation, (2) key process involved, (3) core partnership in innovation, (4) phases of incubation, and (5) funding for sustainability of incubation process.

\subsection{Innovative Design for Variations in Thematic Incubation}

The innovative design of the thematic incubators provides the flexibility of venturing into a selected theme so as to align with the overall agenda of the corporate organization with the global sustainability agenda. The thematic incubation on women entrepreneurship at Mody University cuts through the many layers of societal vulnerabilities. Mody University is an all-women university and is situated in Rajasthan in the western part of India, known for its strong business community. It is envisioned that, with training and resources, women can take on entrepreneurial ventures in the field of risk resilience and sustainability. Doing so, the issues of the women during a disaster and in general can be better understood and tailor-made solutions designed by the women themselves be implemented. Thus, the thematic incubator in this case was development of women entrepreneurship, and enhance SDG 5.

The NIT, Nagpur, is located in a recurring drought-prone area, and Nagpur city is designated as a smart city. The specific theme of the incubator is to focus on SDG 6 (Clean Water and Sanitation) and SDG 11 (Sustainable Cities and Communities). The poor quality of drinking water, inadequate nutrition among women and children are some of the emerging issues to be tackled. The Incubator at Brac University, Dhaka, a city with a very high population density, is focused on the issues of sustainable city planning and design to combat climate change. The thematic incubation can build on creating solutions for public health at the community level and also provide innovations to address the root cause of a health problem which may be linked to an environmental issue.

\subsection{Process of Establishing a Thematic Incubator}

The Thematic Incubators can be set up by the private sector in one or more of the selected themes. The incubators can be set up as the central business model or as a side business of the corporate entity. First and foremost, the corporation has to identify the relevant theme under its sustainability agenda. The themes may vary from specific goals under SDG or priorities of SFDRR. The themes may further be narrowed down to suit the local level problems of the society. The corporation may target its own geographical area or any other location based on consultation with stakeholders. Figure 2 below depicts the process of Incubation.

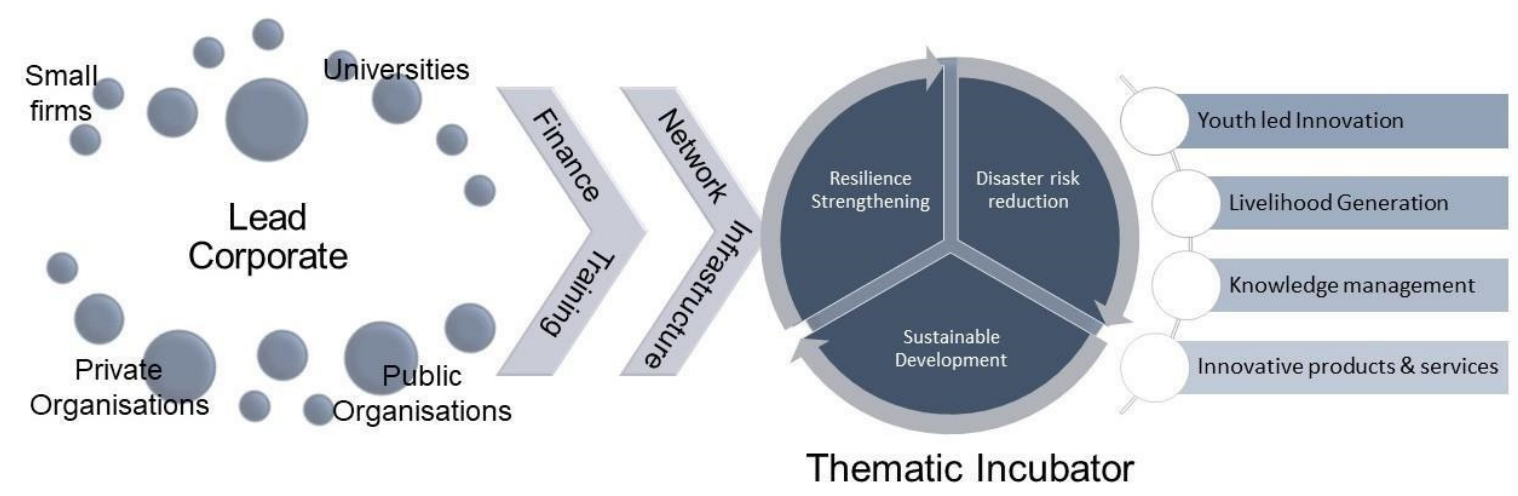

Figure 2. Process of establishment of incubator. 


\subsection{University/Academia Partnership}

According to Reference [59], the interaction between university and company is an indispensable precondition for the materialization of technological progress and improved socioeconomic use of the produced scientific and technological knowledge. The interaction between university and company is a form of scientific and technological cooperation, which contributes in a decisive manner to innovation development. Hence, as the second step, corporations need to identify the relevant academic institutes which corroborate with their selected theme. The database of students and faculty research can be accessed, customized, scaled, repackaged, and presented for possible funding and also for global visibility. Consideration of academic specialization, as well as the regional needs, can be considered.

\subsection{Phases of Incubation}

The process of setting up an Incubator typically takes 3 to 6 years. It can be viewed through four different phases: Inception Phase, Pre-Incubation Phase, Establishment Phase, and Sunset Phase. In the inception phase, the idea of the incubator is promoted among the identified stakeholders; community members; partners, like industry associates and academic institutes; and others who might be interested. The working methodology of the incubator is finalized in this phase with the identified stakeholders. Activities, like hackathons, brainstorming sessions, and awareness generation exercises, are undertaken so as to brainstorm interesting ideas. The next phase of pre-incubation includes idea screening and refinement. The industrial experts are engaged to provide technical support on the concept development of the prototype. This phase aims to understand the existing demand and resources so as to come up with innovative and implementable solutions. In the establishment phase, the selected idea is pilot tested. The incubate is supported with revenue models, financial projections, and other essentials of company management, along with brand development and market linkages. The sunset phase is the graduation phase of the registered incubates. In this phase, they venture out as independent business units. In some cases, the incubators may remain as partners of the newly established firm for 2-3 years so as to smoothen out the exit strategy. As a rule, incubated firms should not be allowed to overstay the agreed period of incubation so as to enable other firms to benefit from the same support.

The incubator functions to train and mentor young entrepreneurs to bring in innovation through new products, services, and integrate research into this process. The thematic incubator for sustainability also has the role of conducting training programs for local stakeholders, like NGOs, municipal offices, and corporates, to align their work with a global vision. It helps local businesses in managing business risks. The thematic incubator can help the various ongoing businesses to integrate SDGs and SFDRR into their product and processes. More importantly, it supports the Micro Small and Medium Enterprises (MSMEs) to establish connections with the global community.

\subsection{Funding Support for Thematic Incubators}

There are two types of funding requirements identified for the incubation, namely; establishment cost, which involves expense incurred in running day to day work of the incubation; and the cost of funding innovation. This includes cost of exposure visits, funding assistance to support innovation from concept to market, and cost of training. In most cases, the first component is borne by the host entity, and a physical space is provided for running the incubation center. In two instances (Mody University and NIT-Nagpur), the thematic incubator is merged, along with the already established incubator leading to sharing of physical space and resources. 


\section{Discussion}

This paper seeks to address some of the key challenges of incubation and knowledge generation with wider stakeholder partnerships. The key learning, which is drawn from the case studies, as well from RIKA's experiences, are summarized below.

\subsection{Setting Up Specific Targets and Stakeholders}

One of these included the difficulty faced by case studies in identifying the right target sector and stakeholders. This can be addressed by working with the identified partners, namely, community, government, and academia and, thereby, through a consultative and participative process the themes of convergence which the partners wish to collaborate on can be identified. The identified theme guides on the selection of inter-connected and relevant sectors. Based on the identified themes, the private sector will find itself in a better and informed position to prioritize its sustainability obligations and make an efficient allocation of available/limited resources. Further, by the inclusion of key partners, like community, government, and academia, the framework will also help the private sector in addressing another identified issue of failing to include the interests of indirect stakeholders, like community, civil organizations, etc., while planning its sustainability requirements. As observed in the process of establishment of incubator with RIKA, the local level challenges can be targeted to incubate ideas focusing on low-cost customized solutions for the community.

Another significant challenge identified earlier is that sustainability is still not being integrated into long-term business strategy by some of the private players who perceive it as an inconsequential priority and often fulfill it as a secondary function without associating it with value creation. The framework proposed in this paper envisages bridging this gap in the perception of the private players whereby they feel they are only contributing their resources for the betterment of society or environment with hardly any benefit to them. The framework explicitly lays down how the private sector can benefit from the multipartnership approach of the thematic incubators. The findings of the research undertaken by academia can help the private sector in not only improving its existing products and services but also in developing the new one.

Further, its partnership with the community provides it with a dedicated pool of customers whose interests have already been taken into consideration while developing the product/service/solution. The feedback of the community can also aid the private sector in creating new markets for itself. Thus, the thematic incubator seems to serve as a successful approach that brings together the critical aspects of sustainability and resilience. Products and services catering to climate and disaster risk reduction are often capital intensive, serve a niche market, and may have a long gestation period to show a tangible impact on ground or have limited commercial profitability.

Uncertainty in implementing climate and allied policies that prompt the market for innovation in technologies and services results in uncertainty of the benefits of undertaking such innovations [33]. This may discourage corporations or investors to lock in their resources for a long duration for little perceived benefits. In the backdrop of this, the importance of national strategies and plans, regulations, and supporting policies cannot be overemphasized in providing the necessary conditions for an incubator to flourish, as well as that of strategic financing in unlocking further investment [60].

\subsection{COVID-19 Pandemic and Opportunities for Innovation}

Case studies have already emerged from various affected countries where innovation labs have come up with innovative products to aid the health industry in times of crisis. The tinkering lab of Indian Institute of Technology, Roorkee, has come up with a low-cost ventilator (Pran Vayu) in collaboration with All India Institute of Medical Sciences (AIIMS), Rishikesh [61,62]. A major breakthrough for the thematic incubation in the context of Public Health Emergency is the scope of implementation of Social Innovation as a LongTerm care. In the current COVID-19 crises, the dependency of the elderly population on 
caregivers has increased. Reference [63] establishes the need for a 'specialized agency' to venture into social innovation for long term care. The thematic incubation provides scope to devise interventions at the local level which cater to the issues of a specific group of society. The thematic incubators can discuss the innovative strategies to make hygiene practices a cultural norm and work on social engineering of voluntary commitment towards the government advisories. Using the multi-stakeholder partnership approach, thematic incubators in collaboration with clinicians, epidemiologists, virologists, health care workers, administrators, and law enforcement agencies can develop a coordinated mitigation strategy.

While the pandemic has led to limited mobility, at the same time, it has heightened the sense of need to have innovation and research in the field of disaster management. The thematic incubators established by RIKA at IIT Roorkee and NIT Nagpur has come forward to organize an online hackathon supported other Higher Education Institutes in India came together to organize an online hackathon (Figure 3). The concept is to encourage students to ideate while under lockdown and share laboratories and other infrastructure available locally with the collaborating universities. And, as a result, the output is co-produced through intensive mentorship, consultation, and funding support. One such example being the application of innovative knowledge in the form of a mobile-based solution application to ease the queue management process at hospitals in the context of COVID-19 pandemic.

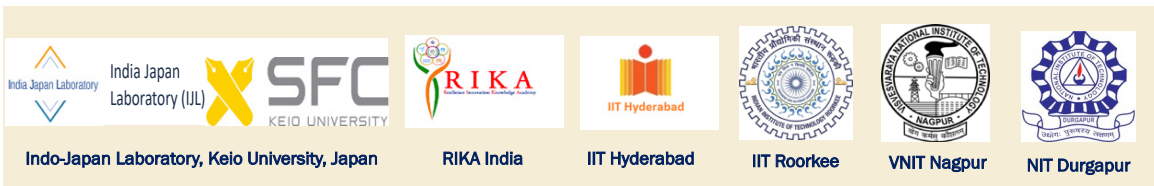

\section{Social Innovation Hackathon 2020}

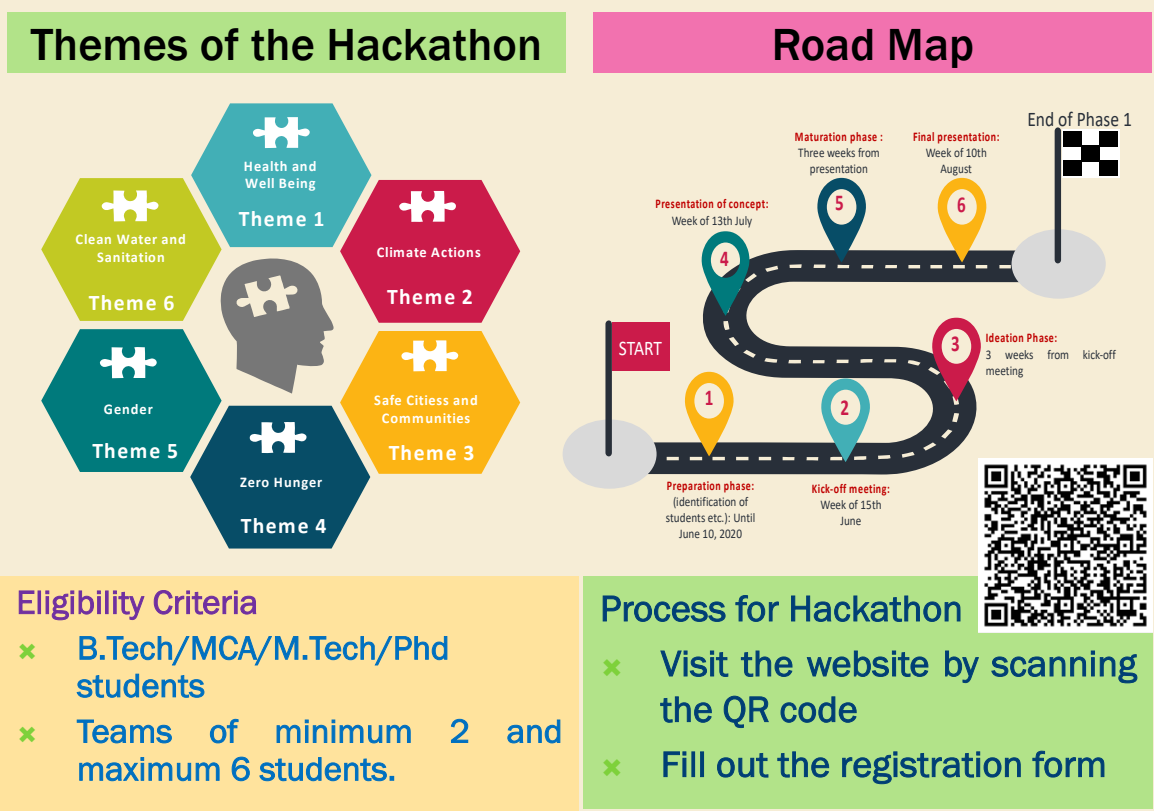

** Selected students will get chance in Winter/Summer Internship with scholarship in following organizations:

Indo-Japan Laboratory (Japan), IIT Roorkee, IIT Hyderabad, NIT Nagpur,
NIT Durgapur
SEED Grant

Figure 3. Social Innovation Online hackathon outline. 


\subsection{Challenges of Thematic Incubation Process}

Ref. [64] has pointed at the need for a high level of exchange among faculty in promoting entrepreneurial academic initiatives. Interestingly, the role of the students has been not highlighted in the available academic studies. This gap is filled by the thematic incubator concept. As observed in the case study of RIKA India, in the initial phase of incubation set up, there is seldom any idea or product that is linked to disaster risk reduction. The perception of disaster linked products among the students and incubator administration seems to be focused on a specific disaster event which is in contrast to the idea of building disaster risk reduction into daily life activities. Hence, there is a need to inculcate perception towards entrepreneurship in the field of risk resilience and sustainability. As noted in the establishment of thematic incubators by RIKA India, in-depth orientation sessions with faculty and students on linkages between disaster risk reduction and innovative business opportunities helped to build enthusiasm. As evidenced by the institutional theory, a culture of innovation in sustainability can be built by institutionalizing the thematic incubator centers. Table 2 below summarizes the key challenges of corporate sustainability and the proposed interventions through thematic incubators. The incubators encourage disruptive ideation. A start-up at an incubation center does not have a set business model and, hence, is at the core of the disruptive force. Because of the digital age, the disruption does not necessarily come from a new technology but can be due to redefining of the value chain, supply network, or marketing approach. The force of disruptive ideation can change the entire architecture of the related business industry. The fruits of disruptive ideation are possible through a consultative process of co-creating and co-designing the knowledge innovation in a simulator program through thematic incubators.

Table 2. Summary of challenges of corporate sustainability and how thematic incubators address those.

\begin{tabular}{|c|c|}
\hline Challenges for Corporate Sustainability & Opportunities for the Thematic Incubators \\
\hline Identification of right target sector/theme & $\begin{array}{l}\text { Convergence of themes under global policy dialogues guide on } \\
\text { the selection of inter-connected and relevant sectors }\end{array}$ \\
\hline Identification of right stakeholders & $\begin{array}{l}\text { Consultative and Participative process with members of } \\
\text { community, academia, NGO, and private sector aid in selection } \\
\text { of right stakeholders on the relevant theme }\end{array}$ \\
\hline Interest of indirect stakeholders remaining unaddressed & $\begin{array}{l}\text { Community consultations provide space for inclusion of their } \\
\text { interests and also build brand value and customer loyalty }\end{array}$ \\
\hline $\begin{array}{l}\text { Corporate sustainability as a long-term strategy with } \\
\text { value creation }\end{array}$ & $\begin{array}{l}\text { The conceptual framework depicts the linkages of sustainability } \\
\text { and resilience and depicts it as a win-win situation for } \\
\text { all stakeholders }\end{array}$ \\
\hline Private sector-academia-government linkages & $\begin{array}{l}\text { Academic research enables innovative solutions to the local } \\
\text { level problems which can be further commercialized } \\
\text { The elements of accountability, partnership, and environmental } \\
\text { sustainability help to strengthen the governance initiatives on } \\
\text { the same }\end{array}$ \\
\hline Public Health: COVID-19 Pandemic & $\begin{array}{l}\text { Inclusion of social innovation in long-term care } \\
\text { Addressing the social cause of public health problems }\end{array}$ \\
\hline Other social sector challenges & $\begin{array}{l}\text { Thematic incubators bridge the gap between use of science and } \\
\text { technology for social innovation } \\
\text { Themes of women entrepreneurship enhance the women } \\
\text { empowerment and leadership in DRR and sustainability } \\
\text { Addresses unemployment by equipping youth with skills } \\
\text { of entrepreneurship }\end{array}$ \\
\hline
\end{tabular}

Lack of understanding among academia on use of research for innovative solutions for DRR, climate change, and sustainability The perception of disaster as one-time event and lack of focus on sustainability and resilience in daily life
Institutionalization of thematic incubators helps to build culture of use of science and technology for innovation for DRR, sustainability, and climate change 


\section{Conclusions}

Thematic incubator for DRR and sustainable development is an innovative approach for co-producing knowledge innovation. It brings together key aspects of sustainability and resilience and provides a perfect blend of implementing the global agendas in a local context through a participative and collaborative approach. Thematic incubator not only helps the society in finding an appropriate sustainable solution to their problem but also creates entrepreneurs and leaders in the society; overall, it is a win-win partnership for all its partners.

The Sendai Framework for Disaster Risk Reduction bats for innovation and technology, along with increased investment in DRR, to develop new innovations for tackling local challenges. Reference [48] points out that the crux of science and technology in supporting policy and decision-making lies in innovations. In this respect, the thematic incubation is the apt tool to bring in products and knowledge services based on scientific research linked to local context. Further, the multi-stakeholder thematic incubator promotes a collaborative vision of welfare and provides better solutions to locally identified needs. The concept of thematic incubators can be explored for global issues and challenges including those related to human rights aspects, corruption, cyber-frauds, human-trafficking, etc., for finding local and contextualized solutions.

The COVID-19 situation, though, has become a hurdle especially for mobility but, at the same time, is also an opportunity to push for innovation. The furthering of Science and Technology is to not only address data gaps and produce technical solutions but, at the same time, look deeper into the socio-economic stressors which will have long term indirect and wider impacts, such as loss of livelihood and economic downturn. The case of social innovation for food provisioning in Naples amid the COVID-19 crisis is a case in point, highlighting the need for social innovations in the coming days to tackle issues beyond health [65]. It can be said that the promotion of social enterprises will be rise in the future as we grapple to look for sustainable local solutions. One major lesson from the present COVID-19 pandemic is the need for flexibility in the process of incubation. Changing the hackathon from a physical to virtual process ensures the continuity of engagement of the stakeholders.

To make this possible, the private sector needs to engage and build partnerships with universities, local communities, and government to support the youth and the community by providing them with a platform and resources for experimenting and nurturing their ideas and, thus, finding innovative solutions for local problems. Some of these ideas can be disruptive and can further pave the way for bringing in new commercial opportunities to the private sector, along with ensuring the principle of profit with purpose. Finally, as the concept of thematic incubators is still in its early stages of development, more research and documentation of the process will reveal its real trajectory.

Author Contributions: Conceptualization by R.C. and R.S.; methodology by all authors (S.B., A.D., R.C. and R.S.), formal analysis by S.B. and A.D., investigation by S.B. and A.D., writing-original draft preparation by all authors, supervision by R.C., R.S. All authors have read and agreed to the published version of the manuscript.

Funding: The publication cost of the paper is supported by Keio University's India Japan Laboratory's (IJL) grant. IJL also provided financial support to Social Innovation Online Hackathon.

Institutional Review Board Statement: Not applicable.

Informed Consent Statement: Not applicable.

Data Availability Statement: Not applicable.

Acknowledgments: The authors acknowledge the support and guidance from all participating universities in the incubation program. The authors also acknowledge support from India Japan Laboratory (IJL) of Keio University in co-organizing the Social Innovation Online Hackathon. IJL provided related logistic, human resource and financial supports. 
Conflicts of Interest: The authors declare no conflict of interest.

\section{References}

1. EM-DAT. The International Disasters Database, Emdat.be. 2020. Available online: https://www.emdat.be/ (accessed on 9 May 2020).

2. Chan, E.Y.Y.; Murray, V. What are the health research needs for the Sendai framework? Lancet 2017, 390, e35-e36. [CrossRef]

3. Schaltegger, S.; Freund, F.L.; Hansen, E.G. Business Cases for Sustainability: The Role of Business Model Innovation for Corporate Sustainability. Int. J. Innov. Sustain. Dev. 2012, 62, 95. Available online: https://www.researchgate.net/publication/256013169_ (accessed on 30 March 2020). [CrossRef]

4. Wu, Q.; He, Q.; Duan, Y. Explicating dynamic capabilities for corporate sustainability. EuroMed. J. Bus. 2013, 8, 255-272. [CrossRef]

5. Norström, A.V.; Cvitanovic, C.; Löf, M.F.; West, S.; Wyborn, C.; Balvanera, P.; Bednarek, A.T.; Bennett, E.M.; Biggs, R.; de Bremond, A.; et al. Principles for knowledge co-production in sustainability research. Nat. Sustain. 2020, 3, 182-190. [CrossRef]

6. Djenontin, I.; Meadow, A. The art of co-production of knowledge in environmental sciences and management: Lessons from international practice. Environ. Manag. 2018, 61, 885-903. [CrossRef] [PubMed]

7. Izumi, T.; Shaw, R.; Djalante, R.; Ishiwatari, M.; Komino, T. Disaster risk reduction and innovations. Prog. Disaster Sci. 2019, 2, 100033. [CrossRef]

8. Mind the Gap: The Continued Divide between Investors and Corporates on ESG. Governance Insights Centre. PwC ESG Pulse. February 2019. Available online: https://www.pwc.com/us/en/services/assets/pwc-esg-divide-investors-corporates.pdf (accessed on 11 March 2020).

9. Who Cares Wins 2005 Conference Report: Investing for Long-Term Value. Available online: https://www.ifc.org/wps/wcm/co nnect/topics_ext_content/ifc_external_corporate_site/sustainability-at-ifc/publications/publications_report_whocareswins 2005_wci_1319576590784 (accessed on 27 February 2020).

10. ESG in Equity Analysis and Credit Analysis. unpri.org. CFA Institute, 2018. Available online: https://www.unpri.org/downlo ad?ac $=4571$ (accessed on 11 March 2020).

11. Chen, J.; Scott, G. Environmental, Social, and Governance (ESG) Criteria. Investopedia. 2020. Available online: https:/ /www.in vestopedia.com/terms/e/environmental-social-and-governance-esg-criteria.asp (accessed on 12 February 2021).

12. Wilson, M. Corporate Sustainability: What Is It and Where does it Come from? Ivey Bus. J. 2003, 67, 1-5. Available online: https://iveybusinessjournal.com/publication/corporate-sustainability-what-is-it-and-where-does-it-come-from/ (accessed on 23 January 2020).

13. Corporate Accountability. Environmental Justice Organisations, Liabilities and Trade. Mapping Environmental JusticeAccountability. Available online: http://www.ejolt.org/2013/05/corporate-accountability/ (accessed on 15 March 2020).

14. Institutional Theory-An overview ScienceDirect Topics, Sciencedirect.com. 2020. Available online: https://www.sciencedirect. com/topics/social-sciences/institutional-theory (accessed on 29 May 2020).

15. Social Network Theory-An overview ScienceDirect Topics, Sciencedirect.com. 2020. Available online: https://www.sciencedir ect.com/topics / psychology / social-network-theory (accessed on 29 May 2020).

16. Rodrigues, M.; Franco, M. The CORPORATE Sustainability Strategy in Organisations: A Systematic Review and Future Directions. Sustainability 2019, 11, 6214. Available online: https:/ / www.mdpi.com/2071-1050/11/22/6214/pdf (accessed on 5 March 2020). [CrossRef]

17. Yin, R.K. Case Study Approach: Design and Methods, 5th ed.; SAGE Publications: Sauzend Oaks, CA, USA, 2014.

18. Zainal, Z. Case Study as a Research Method. 2007. Available online: http://psyking.net/htmlobj-3837/case_study_as_a_researc h_method.pdf (accessed on 31 May 2020).

19. Crowe, S.; Cresswell, K.; Robertson, A.; Huby, G.; Avery, A.; Sheikh, A. The Case Study Approach. BMC Med. Res. Methodol. 2011, 11, 1-9. [CrossRef] [PubMed]

20. Prather, A. A Brief History of 'Investability DNA' in Incubation and Acceleration. Available online: https://www.entrepreneur.c om/article/323468. (accessed on 12 February 2021).

21. Kumar, G.P. Indian Start-ups-Issues, Challenges and Opportunities. 2018. Available online: https://www.researchgate.net/publi cation/323855305_INDIAN_STARTUPS-_ISSUES_CHALLENGES_AND_OPPORTUNITIES (accessed on 23 March 2020).

22. Incubation Support. Department of Promotion of Industry \& Internal Trade. Misnitry of Commerce \& Industry. Government of India. Available online: https://www.startupindia.gov.in/content/sih/en/compendium_of_good_practices/incubationsupp ort.html (accessed on 23 March 2020).

23. Shaw, R.; Izumi, T.; Shi, P. Perspectives of Science and Technology in Disaster Risk Reduction of Asia. Int. J. Disaster Risk Sci. 2016, 7, 329-342. [CrossRef]

24. Accelerators vs. Incubators: What Startups Need to Know. Techrepublic. Available online: https:/ / www.techrepublic.com/artic le/accelerators-vs-incubators-what-startups-need-to-know / (accessed on 23 March 2020).

25. Christofi, A.; Christofi, P.; Sisaye, S. Corporate Sustainability: Historical Development and Reporting Practices. Manag. Res. Rev. 2012. Available online: https://www.researchgate.net/publication/235268602_Corporate_sustainability_Historical_develop ment_and_reporting_practices/citation/download (accessed on 8 June 2020). 
26. Arowoshegbe, A.; Emmanuel, U.; Gina, A. Sustainability and Triple Bottom Line: An Overview of Two Interrelated Concepts. 2018. Available online: https://www.researchgate.net/publication/322367106_SUSTAINABILITY_AND_TRIPLE_BOTTOM_ LINE_AN_OVERVIEW_OF_TWO_INTERRELATED_CONCEPTS/link/5a563e3eaca272bb6963e2f0/download. (accessed on 8 June 2020).

27. Ingram, G.; Nguyen, M.; Bala, M. How Corporations Are Approaching Sustainability and the Global Goals; Brookings: Washington, DC, USA, 2019. Available online: https://www.brookings.edu/blog/up-front/2019/01/08/how-corporations-are-approaching-sust ainability-and-the-global-goals / (accessed on 24 January 2020).

28. Beattie, A. The Three Pillars of Corporate Sustainability; Investopedia: New York, NY, USA, 2019. Available online: https:/ www.in vestopedia.com/articles/investing/100515/three-pillars-corporate-sustainability.asp (accessed on 23 January 2020).

29. Perera, A.; Pino, S.P.D.; Oliveria, B. Aligning Profit and Environmental Sustainability: Stories from Industry; World Resources Institute: Washington, DC, USA, 2013. Available online: https://wriorg.s3.amazonaws.com/s3fs-public/pdf/aligning_profit_and_environ mental_sustainability_stories_from_industry.pdf (accessed on 14 February 2020).

30. McPhearson, T. The Rise of Resilience: Linking Resilience and Sustainability in City Planning. The Nature of Cities. 2014. Available online: https://www.thenatureofcities.com/2014/06/08/the-rise-of-resilience-linking-resilience-and-sustainabilityin-city-planning/ (accessed on 26 March 2020).

31. Marchese, D.; Reynolds, E.; Bates, M.; Morgan, H.; Clark, S.; Linkov, I. Resilience and sustainability: Similarities and differences in environmental management applications. Sci. Total Environ. 2018, 613, 1275-1283. [CrossRef]

32. Norström, A. Principles for Successful Knowledge Co-production for Sustainability Research [Blog]. 2020. Available online: https:/ / futureearth.org/2020/01/21/principles-for-successful-knowledge-co-production-for-sustainability-research/ (accessed on 4 February 2021).

33. United Nations Framework Convention on Climate Change. Climate Technology Incubators and Accelerators; UNFCCC: Bonn, Germany, 2018. Available online: https://unfccc.int/ttclear/misc_/StaticFiles/gnwoerk_static/incubators_index/ee343309e8854 ab783e0dcae3ec2cfa6/c172d2f388234bdbbe3dd9ae60e4d7e9.pdf (accessed on 12 February 2021).

34. Thematic Dialogue on Incubators and Accelerators. UNFCC. Available online: https://unfccc.int/ttclear/events/2018_event2 (accessed on 5 March 2020).

35. Plastrik, P.; Parzen, J. Toward a Sustainable City: The State of Innovation in Urban Sustainability. Urban Sustainability Director's Network. 2013. Available online: https://www.usdn.org/uploads/cms/documents/state-of-innovation.pdf (accessed on 30 March 2020).

36. Mannan, L. 8 Incubators for Startups to Watch out for in Delhi-NCR, YourStory.com. 2020. Available online: https:/ /yourstory.co $\mathrm{m} / 2017 / 12 / 8$-incubators-startups-watch-delhi-ncr (accessed on 9 June 2020).

37. SINE, Sineiitb.org. 2020. Available online: https:/ / sineiitb.org/ (accessed on 9 June 2020).

38. Atal Innovation Mission NITI Aayog, Niti.gov.in. 2020. Available online: https://niti.gov.in/aim (accessed on 9 June 2020).

39. Icreate. 2020. Available online: https:/ / icreate.org.in/ (accessed on 9 June 2020).

40. Centre for Innovation Incubation \& Entrepreneurship (CIIE)—IIMA, Iima.ac.in. 2020. Available online: https://www.iima.ac.in / web / areas-and-centres/research-centres/ciie (accessed on 9 June 2020).

41. T-Hub Leads India's Pioneering Innovation Ecosystem, T-Hub. 2020. Available online: https://t-hub.co/ (accessed on 9 June 2020).

42. Incubators-Startup, Startup.karnataka.gov.in. 2020. Available online: https://startup.karnataka.gov.in/incubators/ (accessed on 9 June 2020).

43. Hub, I. CSR Europe Launches SDG Incubator, Report on Benefits to Europe I News I SDG Knowledge Hub | IISD, Sdg.iisd.org. 2020. Available online: https://sdg.iisd.org/news/csr-europe-launches-sdg-incubator-report-on-benefits-to-europe/ (accessed on 9 June 2020).

44. Incubator-Citizen Science for the 2030 SDG Agenda-Global Young Academy, Global Young Academy. 2020. Available online: https:/ / globalyoungacademy.net/activities/incubator-citizen-science-for-the-2030-sdg-agenda/\#: :text=It\%20aims\%20t o\%20harness\%20the,Sustainable\%20Development\%20Goals\%20(SDGs) (accessed on 9 June 2020).

45. Learn about our Accelerator Program I Accelerators I Google Developers, Google Developers. 2020. Available online: https: / / developers.google.com/community/accelerators (accessed on 9 June 2020).

46. SDG Impact Accelerator I Home Page, SDGIA. 2020. Available online: https:/ / www.sdgia.org/ (accessed on 9 June 2020).

47. The Role of Science, Technology and Innovation Policies to Foster the Implementation of the Sustainable Development Goals (SDGs) Report of the Expert Group "Follow-Up to Rio 20, notably the SDGs"; European Commission: Brussels, Belgium, 2015; ISBN 978-92-79-52716-6. [CrossRef]

48. Science, Technology and Innovation. UNIDO. Available online: https://www.unido.org/our-focus/advancing-economic-compe titiveness/investing-technology-and-innovation/investment-and-technology/science-technology-and-innovation (accessed on 3 March 2020).

49. Mormina, M. Science, Technology and Innovation as Social Goods for Development: Rethinking Research Capacity Building from Sen's Capabilities Approach. Sci. Eng. Ethics 2019, 25, 671-692. [CrossRef]

50. Chatterjee, R.; Shiwaku, K.; Das Gupta, R.; Nakano, G.; Shaw, R. Bangkok to Sendai and Beyond: Implications for Disaster Risk Reduction in Asia. Int. J. Disaster Risk Sci. 2015, 6, 177-188. [CrossRef] 
51. Tukiainen, T.; Leminen, S.; Westerlund, M. Cities as Collaborative Innovation Platforms. Technol. Innov. Manag. Rev. 2015, 5, 16-22. [CrossRef]

52. Dodds, F. Multi-stakeholder Partnerships: Making Them Work for the Post-2015 Development Agenda. United Nations Department of Economic and Social Affairs. Available online: https://sustainabledevelopment.un.org/content/documents/16 192015partnerships_background_note.pdf (accessed on 16 March 2020).

53. The Science and Technology Roadmap to Support the Implementation of the Sendai Framework for Disaster Risk Reduction 2015-2030. UNISDR, 2016. Available online: https:/ /www.preventionweb.net/english/professional/policies/v.php?id=65131 (accessed on 23 March 2020).

54. "How Dare You?" This is Greta Thunberg's Passionate Cry for Climate Action. ABC News. 2019. Available online: https: / / www.youtube.com/watch?v=N94eP2jKQWw (accessed on 26 March 2020).

55. Minniti, M. Gender Issues in Entrepreneurship. Found. Trends Entrep. 2019, 5, 497-621. [CrossRef]

56. Kelley, D.J.; Baumer, B.S.; Brush, C.; Greene, P.G.; Mahdavi, M.; Cole, M.M.M.; Dean, M.; Heavlow, R. Women's Entrepreneurship 2016/2017 Report. Available online: http://www.fundacionmicrofinanzasbbva.org/revistaprogreso/wp-content/uploads/201 7/12/gem-womens-2016-2017-report-v11df-1504758645.pdf (accessed on 25 May 2020).

57. As Pandemic Rages, Women and Girls Face Intensified Risks. UNFPA, 2020. Available online: https://www.unfpa.org/news/p andemic-rages-women-and-girls-face-intensified-risks (accessed on 2 April 2020).

58. Madjdian, D. Gender, Intra-Household Food Allocation and Social Change in Two Himalayan Communities in Nepal. 2018 Available online: https:/ / www.researchgate.net/publication/324269770_Gender_intra-household_food_allocation_and_soci al_change_in_two_Himalayan_communities_in_Nepal (accessed on 4 April 2020).

59. Rizzi, D.I.; Wescinski, J.V.; Poli, O.; Jacoski, C.A. The Importance of Incubation Processes from the Perspective of Incubated and Graduated Companies. JISTEM J. Inf. Syst. Technol. Manag. 2019, 14, 263-279. [CrossRef]

60. Kosolapova, E. TEC, CTCN, GCF Seek Ways to Boost Tech Incubators and Accelerators for Climate Action. SDG Knowledge Hub, 2018. Available online: https:/ / sdg.iisd.org/news/tec-ctcn-gcf-seek-ways-to-boost-tech-incubators-and-accelerators-for-cli mate-action/ (accessed on 17 February 2020).

61. Anderson, R.M.; Heesterbeek, H.; Klinkenberg, D. Hollingsworth TD. How will Country-Based Mitigation Measures Influence the Course of the COVID-19 Epidemic? Lancet 2020, 395, 931-934. Available online: https://www.thelancet.com/journals/lance t/article/PIIS0140-6736(20)30567-5/fulltext (accessed on 2 April 2020). [CrossRef]

62. Basu, S.D. IIT Roorkee Develops Low-Cost Portable Ventilator to Tackle COVID-19, 2020. Economic Times. 2 April 2020. Available online: https:/ / economictimes.indiatimes.com/news/politics-and-nation/iit-roorkee-develops-low-cost-portable-ventilator-to -tackle-covid-19/articleshow /74954080.cms?utm_source=contentofinterest\&utm_medium=text\&utm_campaign=cppst (accessed on 5 January 2021).

63. Casanova, G.; Principi, A.; Lamura, G. Social Innovation in Long-Term Care: Lessons from the Italian Case. Int. J. Environ. J. Public Health. 2020, 17, 2367. [CrossRef] [PubMed]

64. Mansano, F.H.; Pereira, M.F. Business Incubators as support mechanisms for the economic development: Case of Maringá's technology incubator. Int. J. Innov. 2016, 4, 23-32. [CrossRef]

65. Cattivelli, V.; Rusciano, V. Social Innovation and Food Provisioning during Covid-19: The Case of Urban-Rural Initiatives in the Province of Naples. Sustainability 2020, 12, 4444. [CrossRef] 